\title{
PROCESSING AND RECYCLING OF RUBBER AND OIL WASTES INTO HYDROCARBON FUEL BY METHOD OF PHYSICO-CHEMICAL ACTIVATION
}

\author{
Mykola Gorbunov ${ }^{1}$, Alexandr Kravchenko ${ }^{2}$, Juraj Gerlici ${ }^{3}$, \\ Kateryna Kravchenko ${ }^{3}$, Vladimir Hauser ${ }^{3}$, Tomas Lack ${ }^{3}$ \\ ${ }^{1}$ Volodymyr Dahl East Ukrainian National University, Ukraine; \\ ${ }^{2}$ Zhytomyr State Technological University, Ukraine; ${ }^{3}$ University of Zilina, Slovakia \\ gorbunov0255@gmail.com, avtoap@ukr.net,juraj.gerlici@fstroj.uniza.sk, \\ kkatherina@ukr.net, vladimir.hauser@fstroj.uniza.sk, tomas.lack@fstroj.uniza.sk
}

\begin{abstract}
Worn tires that are taken to waste dump pollute the environment for a long time due to high resistance to external factors (the durability of a tire in water is 1500-2000 years, in the atmosphere $-50-60$ years). When the worn tires are burned, soot is emitted into the atmosphere and toxic gases (biphenyl, anthracene, fluorentane, pyrene, benzapiren), which have a harmful effect on the environment (soils, water, air). Worn oils are one of the most significant sources of environmental pollution. This paper deals with the processing of worn tires and used oils. The limitation of the oil-based fuel reserves lays a pressure on finding their substitute replacement by alternative ways of production. Worn tires and lubricating oils are valuable polymeric raw materials: 1 ton of tires contains about $700 \mathrm{~kg}$ of rubber, which can be reused for fuel production. An alternative method of obtaining fuel is proposed. An analysis of oil recycling methods is presented. Consideration of the efficiency of the use of ultrasonic action and microwave radiation in the used oil recycling process is given. The use of ultrasonic radiation in the process line for purification of waste oil allows it to be separated from solid inclusions by a low energy consumption process and absence of additional costs (gas, solvents, etc.). The total oil cleaning will be $0.4-2 \mu \mathrm{m}$. An improved recycling technology for used oils is presented. The method for producing an alternative hydrocarbon fuel, developed by the authors, combines the processing of worn tires and worn lubricating oil in the presence of the proposed rubber decomposition activators. The use of this method speeds up the process of decomposition, processing and mixing, improves the quality of the resulting fuel. The liquid fuel output is $70 \%$ by weight of the rubber-oil wastes processed, gases are $5 \%$ by weight, solid hydrocarbon residue $20 \%$ and metal $5 \%$.
\end{abstract}

Keywords: fuel, tires, oils, recycling, ozone.

\section{Introduction}

The limitation of the amount of the fuel reserve of petroleum origin creates pressure on finding its substitute by alternative methods of its production [1-5]. Alternative fuels are mainly obtained from raw materials of other than petroleum origin (alcohols, ethers) obtained industrially from coal, peat, slate and biomass. Prospective is also the use of mine methane and hydrogen as fuel, the use of electricity from renewable resources, as well as the generation of fuels by recycling of used materials.

In the production of fuel it is necessary to take into account its price, availability, safety of use, as well as the influence of its combustion products on the environment. In this context, the method of obtaining fuel from used rubber-oil materials, which allows to achieve an economic effect and also clean the environment from these wastes, is evaluated in this paper.

Dramatic growth in the number of used tires around the globe was recorded due to increasing numbers of vehicles on the road. According to van Beukering and Janssen [6;7]; approximately 800 million tires are discarded around the globe annually. This figure is estimated to increase by $2 \%$ every year. Similarly, Sienkiewicz et al. [6;8] reported the annual global production of tires about 1.4 billion units, which corresponds to an estimated 17 million tons of used tires each year.

According to the previous research by Zitte et al [9;10], used oil is described as dirty oil, black oil, burnt oil, old oil removed from vehicles, used oil from engines and used oil product removed from the engine after being used for a period of 2-5 months. Oil is a synthetic lubricant used in automobile engines, generators and other machines. It is one of the most dangerous sources of pollution $[9 ; 10]$.

Worn tires and lubricating oils are a valuable polymeric raw material. One ton of tires contain approximately $700 \mathrm{~kg}$ of rubber that can be used to produce fuel [1]. One alternative way to solve the issues of scrap tires management is to transform scrap tires into fuels [11] and other useful chemicals via thermochemical techniques, such as combustion [12], pyrolysis [13-14], gasification [15], and liquefaction [16]. 
Among the thermal destruction technologies, the pyrolysis process seems to be more attractive in comparison with the other treatments in terms of minor environmental impact. The process gives, as by-products, gases, oils and char (solid residue) that, after the appropriate upgrading treatment, might have high added value through making them available in the market [17].

Recently, an innovative technology, based on the plasma torch gasification, seems to be the most effective and environmentally friendly method for biomass/solid waste treatment and energy utilization $[11 ; 15]$.

\section{The problem analysis}

Worn tires are one of the toughest polymeric wastes. In 2000, the total amount of worn-out, nonrecycled tires reached in Europe 2.5 million tons, US 2.8 million tons, in Japan 1.0 million tons, in the countries of the former Soviet Union 1.5 million tons [2;5]. Tires that are disposed at landfills represent a long-term environmental burden due to their high resistance to external factors. According to foreign studies, tire decomposition in an aquatic environment takes 1500-2000 years, under atmospheric conditions 50-60 years. When burning worn tires, soot and toxic gases (biphenyl, anthracene, fluorentan, pyrene, benzapyrene) are released into the atmosphere and have a harmful effect on the environment. The contact of tires and groundwater is accompanied by the elution of a number of toxic organic compounds such as diphenylamine, dibutyl phthalate, phenanthrene and the like. Currently, tire disposal is carried out by various methods (Fig. 1).

Oils of petroleum origin are widely used in the operation of modern equipment. The volume of lubricant consumption increases and consequently also the volumes of used oils. Used petroleum products are toxic, have a low degree of biodegradability (10-30\%), are harmful wastes that are subject to collection and disposal and, in some cases, complete elimination $[1 ; 9 ; 10]$. The problem of organizing collection and regeneration of used lubricating oils does not make it possible to stabilize the ecological situation and thus supplement the sources of propellants and lubricants based on their rational use.

\section{WORN TIRES DISPOSAL}

\section{$\begin{array}{llllllllll}\mathbf{M} & \mathbf{E} & \mathbf{T} & \mathbf{H} & \mathbf{O} & \mathbf{D} & \mathbf{S}\end{array}$}

\begin{tabular}{|c|c|c|c|}
\hline $\begin{array}{l}\text { - hot } \\
\text { vulcanisation; } \\
\text { - cold } \\
\text { vulcanisation }\end{array}$ & $\begin{array}{l}\text { - storaging; } \\
\text { - burning }\end{array}$ & $\begin{array}{l}\text { - cryogenic crumbing; } \\
\text { - barodestructive method; } \\
\text { - mechanical methods; }\end{array}$ & $\begin{array}{l}\text { - cracking; } \\
\text { - pyrolysis; } \\
\text { - low temperature } \\
\text { pyrolysis; } \\
\text { - dissolving in an organic } \\
\text { solvent; } \\
\text { - thermal processing }\end{array}$ \\
\hline \multicolumn{4}{|c|}{$\mathbf{P}$} \\
\hline Restored & $\begin{array}{l}\text { No usable } \\
\text { products }\end{array}$ & Rubber crumb & $\begin{array}{c}\text { Low-quality hydrocarbon } \\
\text { fuel }\end{array}$ \\
\hline
\end{tabular}

\section{Fig. 1. Methods of disposal of used tires}

Used oil lubricants are one of the major sources of environmental pollution. Their leakage into the soil and water reservoirs outweigh the accidental leakages and oil losses in mining, transport and processing. In this context, full or partial processing of used oils is of great importance. The basic products of disposal of used oils are thermal energy, regenerated oils, secondary petroleum products, biomass. The basic methods of disposal of used oils include their storage in underground tanks, combustion, coagulation, sorption, extraction, filtration, separation, vacuum heating, catalytic hydrogenation, vacuum distillation, microbial mass production.

In the current stage of industrial development introducing the production from secondary raw materials is a serious and topical issue, especially from used oils representing a valuable source of raw materials for obtaining petroleum products - assuming reliable recycling. Regeneration of used oils in order to fully restore their initial qualities seems to be one of the most effective recycling methods.

In the oil operation process they accumulate oxidation products, contaminants and other adulterants that rapidly reduce the quality of the oils. The ability of oils to prevent wear deteriorates 
proportionately to the number of the engine operating hours. Research [2] on the physicochemical characteristics of engine oils shows that the worst tribological characteristics of engine oils were displayed by oils contaminated by the products of wear of engine parts, soots and dust. The most significant deterioration in the ability of oils to prevent wear occurs when oil is contaminated with products of insoluble precipitates (IP) consisting of wear products, soots released during incomplete combustion, atmospheric dust, and the like. If IP forms $0-0.4 \%$ of the volume of oil charge, the deterioration in the ability of oils to prevent wear is practically unnoticeable. When they occur in the amount of $0.6 \%$ of the IP volume, the speed of wear increase rises - wear takes place 2.7 times faster than if the oil without IP was used. The wear increase rate is then stabilized until the IP forms $1.2 \%$ of the volume of the oil charge. With further increase in the IP concentration up to $2 \%$ of the volume of oil charge, we can observe an increase in wear with an exponential rate up to 20 times the original value [2].

Oils containing polluting adulterants are not able to satisfy the required requirements and should be replaced by new or regenerated oils.

The regeneration of used oils is based on physical, physical-chemical and chemical processes aimed at the removal of aging products and oil contamination. The sequencing of the technological process methods is presented in Fig. 2 [1-19].

The most simple methods of removing liquids and mechanical impurities from the oil charge seem to be sedimentation and evaporation. However, the sedimentation process is very timeconsuming, heating and evaporation are energy-intensive and cause ecological burden on the environment.

Used oils regeneration methods

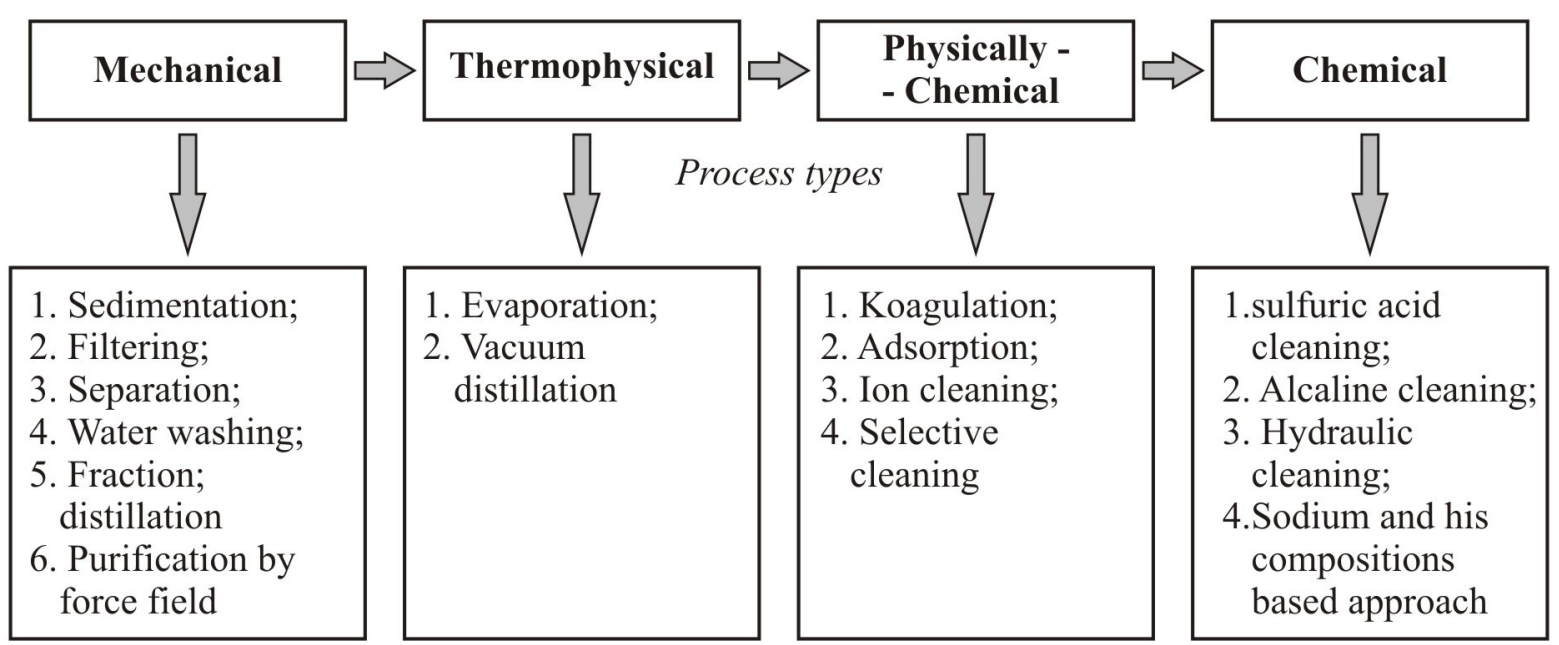

Fig. 2. Technological lines for regeneration of used oil

Based on the research, an innovative oil purification technology has been developed, allowing to reduce the regeneration time, increase the energy efficiency and make the whole process more ecological.

\section{Research results}

In the oil purification technological line separation of solids from the total volume appears as one of the major stages. It is proposed to implement this step, based on the use of mechanical energy of high intensity (more than $20 \mathrm{kHz}$ ) ultrasonic waves that propagate in different materials and use their influence on liquid, solid and gaseous substances.

As the ultrasonic waves propagate in the environment, the areas with increased and reduced pressures alternate, with the compression amplitude always corresponding to the pressure reduction amplitude and their alternation corresponds to the frequency of the ultrasonic waves, which causes the liquid to be sprayed on the surface of the liquid-gas contact.

The most widespread theory describing the mechanism of acoustic spraying of liquids is the theory of cavitation-wave spraying of liquids. According to this theory, developed by Bohuslavsky 
and Eknadiosianc [20] and subsequently extended by Novicky [21], spraying is carried out by breaking liquid droplets from the vertices of standing capillary waves, parametrically excited on the surface of the liquid-air contact as a result of liquid surface churning during collapse of cavitation bubbles (Fig. 3). Since the solid particles have a considerably higher density and weight, the liquid fraction (oil) is sprayed from the liquid-gas contact surface, while the solid fraction is unable to overcome this barrier [22].

The use of ultrasound in the oil purification technological line enables it to separate from solids at a low energy consumption of the process, with no extra expenses for gases, solvents, etc.

After separation of the oil from the base mass of impurities, final purification is required using a fine filter. Before fine filtering of the oil, special heaters that are energy-inefficient are currently being used to decrease the viscosity and increase the leakage efficiency of the oil through the filter. Based on the research performed, it has been found that microwave equipment can be used as a thermal energy carrier. This solution also allows to reduce energy losses and increase the efficiency of oil heating.

In traditional (contact) heating methods, the object temperature rise is progressing in the direction from the surface of the heater. If the thermal conductivity of the fabric is low, as it is the case with the dielectric, heat treatment of the fabric is carried out slowly, with local overheating of the heater.

Changing the traditional contact methods of heating for a non-contact, microwave energy using method enables a more intense temperature rise and more uniform heating as a result of the waves penetrating into the depth of the fabric where the conversion of their energy into heat takes place. Therefore, the heating itself does not take place in the contact of the liquid with the heating body, but in the entire volume of the liquid.

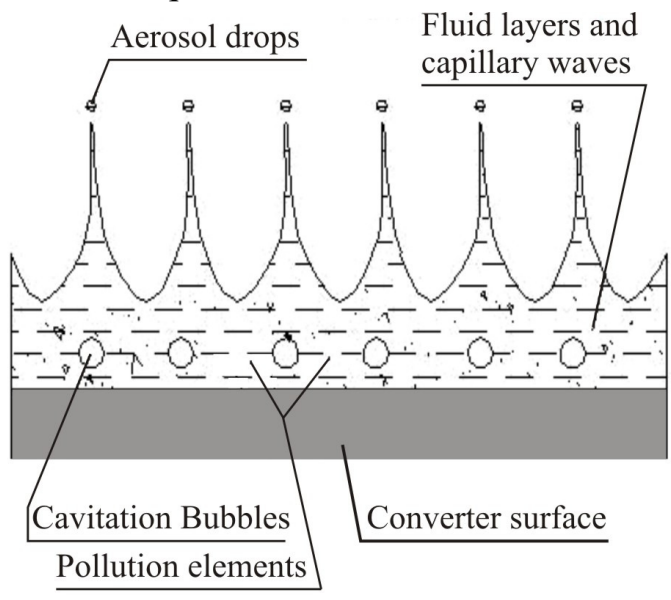

a)

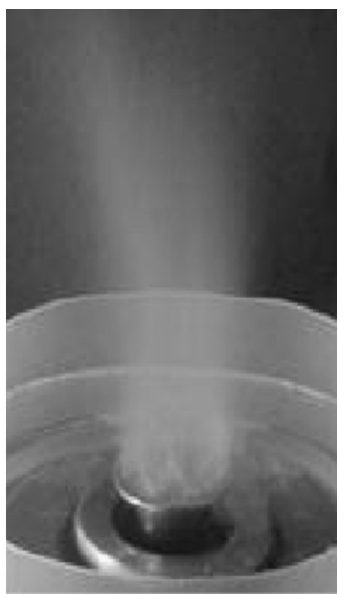

b)

Fig. 3. Oil spraying mechanism from liquid-gas contact surface: $a$ - scheme; $b$ - photograph [10]

Microwave heating (MWH) appears as an ecologically pure heating method because local overheating appears in the process and thus the generation of combustion products is prevented. In addition, the simplicity of microwave energy conversion to heat allows for high heating speeds [23].

\section{The principle of the proposed technology of regenerating used oil}

Used oil is gathered into the tank 1 (Fig. 4). The K1 concentrator excites ultrasonic waves, making the fluid in the tank 1 rise to a higher level. The effect of ultrasound waves causes the active process of spraying the liquid from the surface. A mixture of atomized liquid and air forms a stream, which is directed to the tank 2 . The entire liquid fraction accumulates in the tank 2 , the solids remaining in the tank 1.

A electromagnetic channel 5 is located in the conduit 4, controlled by the microprocessor control unit (MCU) 6. After collecting all the oil in the tank 2, the electromagnetic valve 5 is closed and the control unit 6 triggers the microwave heater 10. The oil in the tank 2 is exposed to microwave radiation, which generates friction at a molecular level and thus reduces the viscosity of the oil. The viscosimeter 7 measures the viscosity of the oil. When the desired value is reached, the microwave heating is switched off and the second electromagnetic valve 8 opens. 


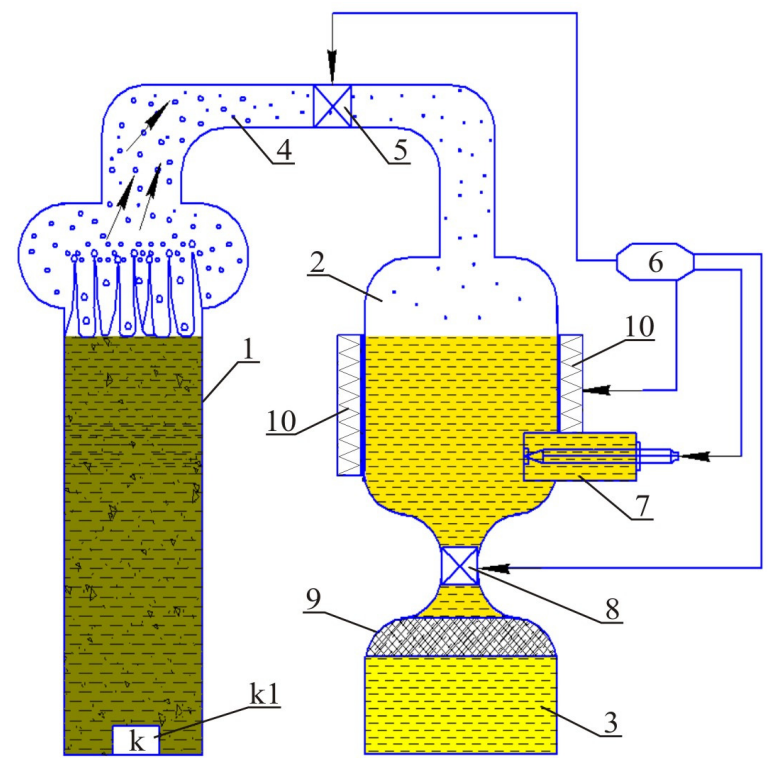

Fig. 4. Scheme of device for regenerating used oil [Patent UA 81723]

In the final step of cleaning the oil from the mechanical impurities, it is filtered by a finecleansing filter 9. In the fine-cleansing filter, a mesh-shaped element consisting of specifically interlaced fibers is used. The fineness of the cleaning is 1-10 $\mu \mathrm{m}$. To ensure even finer cleaning (0.4$4 \mu \mathrm{m})$, it is possible to supplement the filter with a magnetic cleaner, which achieves a cleaning fineness of 0.4-2 $\mu \mathrm{m}$. The regenerated purified oil is collected in the tank 3 .

The proposed technology for cleaning used oil is environmentally harmless, it allows to accelerate the regeneration process and to get a high quality final product.

\section{Method for obtaining an alternative hydrocarbon fuel from rubber -oil waste}

The most promising method of recycling used rubber-oil wastes seems to be their use in the production of alternative hydrocarbon fuels.

The method of obtaining an alternative hydrocarbon fuel developed by the authors combines the treatment of used tires and used lubricating oils. This method uses the used lubricating oil as a solvent of rubber as well as a number of other physicochemical effects (Patents UA 48571, 48875, 66004, 97701), which leads to increased manufacturability and speed of the fuel production process, as well as making it more economical. The use of these secondary raw materials is economically advantageous - these materials have a relatively low purchase price.

The proposed method is illustrated in Fig. 5, where a hydrocarbon fuel production device along with the used process sequence is shown.

The rubber materials are inserted into the pyrolysis apparatus 1 via the hopper. To dissolve the rubber, low-grade petrol is added from the reservoir 2 in the ratio 1:1, the mixture is stirred and afterwards used lubricating oil is added to the obtained product in the ratio 1:1. Later, the apparatus 3 is activated, which creates ultrasonic waves in the vessel, speeding up the dissolution process of the rubber. Simultaneously, gaseous ozone is emitted through the mixture, which is produced in the generator 4 .

In the second stage of dissolving rubber wastes the pyrolysis apparatus triggers into operation the high-frequency electrodes 5. The high-frequency current heats up the metallic elements of the batch mixture, which accelerates the decomposition process of the rubber.

In the last step, the electromagnets 6 are switched on alternately, forming an electromagnetic field. The metal elements alternately move from one magnet to another. The electromagnets thereby cause movement of the mixture. Concurrently, the water from the tank 7 is transported by means of the pump 8 to the evaporator 9 where it vaporizes and the vapor is emitted through the mixture. The gurgitation additionally mixes the mixture, which accelerates the decomposition process of the rubber and the formation of a homogeneous mixture suitable for the production of hydrocarbon fuel - both liquid and gaseous. 


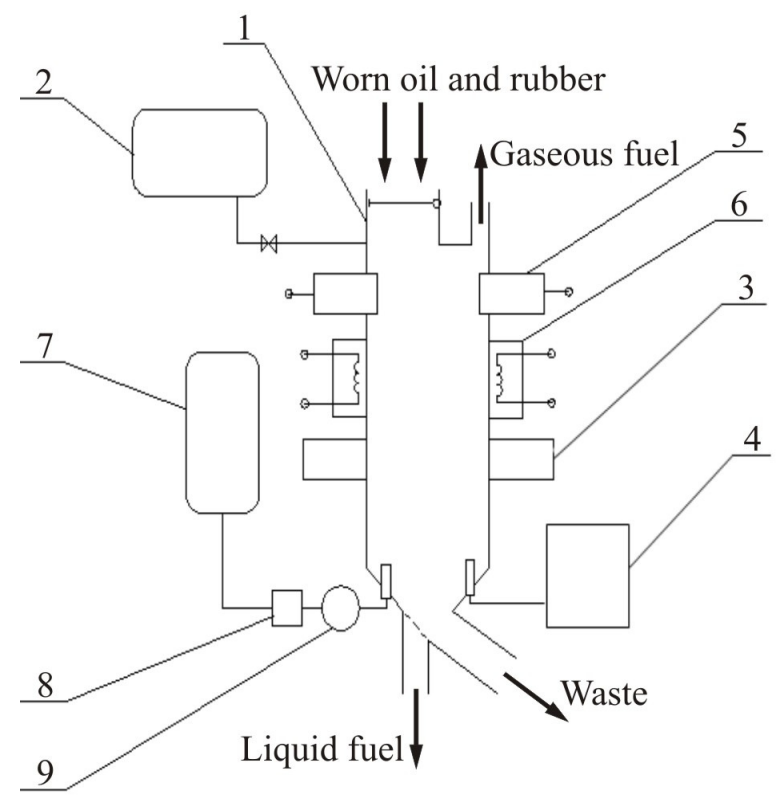

Fig. 5. Method of obtaining liquid and gaseous hydrocarbon fuel from rubber-oil wastes produced in operation of vehicles: 1 - body of pyrolysis apparatus; 2 - low quality hydrocarbon fuel tank; 3 - source of ultrasound waves; 4 - ozone generator; 5 - high-frequency current electrodes; 6 - electromagnet; 7 water tank; 8 - pump; 9 - evaporator

Under the effect of ozone, rapid oxidation of rubber wastes occurs in conjunction with the breakdown of molecular and intramolecular bonds [24]. Therefore, if there are microcracks on the surface of the rubber, the amount of which is significant in worn tires, the ozone molecules begin to act on the molecules that are on the surface of the cracks. This causes rapid growth of cracks, material breakage, and separation of rubber from metal reinforcement.

The reaction takes place at very low energy consumption. It can be stated that ozone particle disruption of a specified size requires 5 to 10 times less energy consumption than cryogenic disturbance.

\section{Conclusions}

1. With the vigorous rise of the transportation industry, used tires, which were once called "black pollution", have become a critical threat to the human environment.

2. Used oil is a synthetic lubricant used in automobile engines, generators and other machines. It is one of the most dangerous sources of pollution.

3. The use of the proposed method accelerates the process of decomposition, recycling and formation of the mixture, increasing the quality of the fuel obtained.

4. When recycling in this manner 6 tons of raw material ( 3 tons of rubber materials per 3 tons of used lubricating oil), the productivity of the method is as follows: 4.2 tons of liquid fuel; 0.3 tons of gaseous fuel; 1.2 tons of solid hydrocarbon residue; 0.3 tons of metal. The liquid fuel output is $70 \%$ by weight of the rubber-oil wastes processed, gases are $5 \%$ by weight, solid hydrocarbon residue $20 \%$ and metal $5 \%$.

\section{References}

[1] Соловьев Е.М., Захаров Н.Д. Переработка и использование отходов шинной промышленности (Recycling and use of waste tire industry). Moscow, ISSN 0233-5727, 1983, 64 p. (In Russian).

[2] Lyons L. The recycling of tires Tire \&Accessories. UK, 3, 2000, pp. 11-12.

[3] Dizo J., Barta D., Blatnicky M. Improvement driving characteristics of electric tricycle. Engineering for Rural Development 17, 2018, pp. 2123-2128.

[4] Gerlici J., Sakhno V., Yefymenko A. etc. The stability analysis of two-wheeled vehicle model. MATEC Web of Conferences. Vol. 157, 14 March 2018, Article number 01007. 22nd Slovak- 
Polish Scientific Conference on Machine Modelling and Simulations, MMS 2017; Sklene Teplice; Slovakia; 5 September 2017 through 8 September 2017; Code 135294.

[5] Kravchenko A., Sakno O., Lukichov A. Research of dynamics of tire wear of trucks and prognostication of their service life. Transport Problems 7(4), pp. 85-94.

[6] Ramarad S., Khalid M., Ratnam C.T., Luqman Chuah A., Rashmi W. Waste tire rubber in polymer blends: A review on the evolution, properties and future. Progress in Materials Science 72, 2015, pp. 100-140.

[7] Beukering PJH, Janssen MA. Trade and recycling of used tyres in Western and Eastern Europe. Resour Conserv Recycl 2001;33:235-65.

[8] Sienkiewicz M., Kucinska-Lipka J., Janik H., Balas A. Progress in used tyres management in the European Union: a review. Waste Manage, 2012;32:1742-51.

[9] Aisha-Lul Ahmed Nur, Emmanuel Kutiote J.O., Patricia Tarlue J.V., Nasir Umar A., Madina Ahmed Nur, Pius Mbuya Nina. Assessment of used oil management at the filling stations within makindye division in Kampala. African Journal of Environment and Natural Science Research, vol. 2, Is. 1, 2019, pp. 77-85.

[10]Zitte LF, AWaadu GDB, Okorodite CG. Used-oil Generation and its Disposal along East-West Road, Port-Harcourt Nigeria, international journal of waste Resources 2016, 6:195 dol: 10.417212252-5211.1000195.

[11]Xiao-Jie Liu, Feng Wang, Lu-Lu Zhai, Yu-Ping Xu, Long-Fei Xie, Pei-Gao Duan. Hydrotreating a waste engine oil and scrap tire oil blend for production of liquid fuel. Fuel, vol. 249, 2019, pp. 418-426.

[12] Singh S., Nimmo W., Tayyeb J.M., Williams P.T. Co-combustion of pulverized coal with waste plastic and tire rubber powders. Energy Fuel 2011, vol. 25 (1), pp. 108-118.

[13] Song Z, Yang Y, Zhou L, Liu L, Zhao X. Gaseous products evolution during microwave pyrolysis of tire powders. International Journal of Hydrogen Energy, vol. 42, Is. 29, 2017, pp. 18209-18215.

[14]Elbaba I.F., Wu C., Williams P.T. Hydrogen production from the pyrolysis-gasification of waste tyres with a nickel/cerium catalyst. International Journal of Hydrogen Energy, vol. 36, Is. 11, 2011, pp. 6628-6637.

[15] Sanlisoy A., Carpinlioglu M.O. A review on plasma gasification for solid waste disposal. International Journal of Hydrogen Energy, vol. 42, Is. 2, 2017, pp. 1361-1365.

[16] Money D.M., Harrison G. Liquefaction of scrap automobile tyres in different solvents and solvent mixes. Fuel, vol. 78, Is. 14, pp. 1729-1736.

[17] Galvagno S., Casu S., Casabianca T., Calabrese A., Cornacchia G. Pyrolysis process for the treatment of scrap tyres: preliminary experimental results. Waste Management 22, 2002, pp. 917-923.

[18]Шашкин П.И, Брай И.В. Регенерация отработанных нефтяных масел (Regeneration of used petroleum oils) Moscow, 1970. 303 p. (In Russian).

[19]Пальгунов П.П., Сумароков М.В. Утилизация промышленных отходов (Industrial Waste Disposal). Moscow. Стройиздат. 1990. 352 p. (In Russian).

[20]Богуславский Ю.Я., Экнадиосянс О.К. О физическом механизме распыления жидкости акустическими колебаниями (On the physical mechanism of spraying a fluid by acoustic fluctuations). Акуст. Ж.- Т. 15. Вып. 1, 1969, pp. 16 - 24. (In Russian).

[21]Новицкий Б.Г. Применение акустических колебаний в химико-технологических процессах (The use of acoustic fluctuations in chemical-technological processes). Moscow, Химия, 1983. 192 p. (In Russian).

[22] Хмелев В.Н., Шалунов А.В., Смердина Е.С. Кавитационное распыление вязких жидкостей (Cavitation spraying viscous liquids). Новосибирск: НГТУ, 2006. (In Russian). [online] [01.03.2019]. Available at: http://u-sonic.ru/downloads/edm06/spray_rus.pdf

[23] Окресса Э. СВЧ - энергетика. Применение энергии СВЧ в промышленности (Microwave energy. The use of microwave energy in industry). T.2. Moscow: Изд. Мир, 1971. 272 p. (In Russian).

[24] Разумовский С. Д., Заиков Г. Е. Атмосферный озон и земная резина (Atmospheric ozone and terrestrial rubber). Химия и Жизнь №5, 1987. pp. 36-40. (In Russian). 